\title{
Qualitative perspectives of the North Carolina healthy food small retailer program among customers in participating stores located in food deserts
}

Lindsey Haynes-Maslow ${ }^{1 *}$, Stephanie B. Jilcott Pitts², Kathryn A. Boys ${ }^{3}$, Jared T. McGuirt ${ }^{4}$, Sheila Fleischhacker ${ }^{5}$, Alice S. Ammerman ${ }^{6}$, Nevin Johnson², Casey Kelley ${ }^{7}$, Victoria E. Donadio², Ronny A. Bell ${ }^{8}$ and Melissa N. Laska ${ }^{9}$

\begin{abstract}
Background: The North Carolina Healthy Food Small Retailer Program (NC HFSRP) was established through a policy passed by the state legislature to provide funding for small food retailers located in food deserts with the goal of increasing access to and sales of healthy foods and beverages among local residents. The purpose of this study was to qualitatively examine perceptions of the NC HFSRP among store customers.

Methods: Qualitative interviews were conducted with 29 customers from five NC HFSRP stores in food deserts across eastern NC. Interview questions were related to shoppers' food and beverage purchases at NC HFSRP stores, whether they had noticed any in-store efforts to promote healthier foods and beverages, their suggestions for promoting healthier foods and beverages, their familiarity with and support of the NC HFSRP, and how their shopping and consumption habits had changed since implementation of the NC HFSRP. A codebook was developed based on deductive (from the interview guide questions) and inductive (emerged from the data) codes and operational definitions. Verbatim transcripts were double-coded and a thematic analysis was conducted based on code frequency, and depth of participant responses for each code.
\end{abstract}

Results: Although very few participants were aware of the NC HFSRP legislation, they recognized changes within the store. Customers noted that the provision of healthier foods and beverages in the store had encouraged them to make healthier purchase and consumption choices. When a description of the NC HFSRP was provided to them, all participants were supportive of the state-funded program. Participants discussed program benefits including improving food access in low-income and/or rural areas and making healthy choices easier for youth and for those most at risk of diet-related chronic diseases.

Conclusions: Findings can inform future healthy corner store initiatives in terms of framing a rationale for funding or policies by focusing on increased food access among vulnerable populations.

Keywords: Healthy corner store, Food policy, Nutrition legislation, Qualitative data collection and analysis, Customer perspectives

\footnotetext{
* Correspondence: Lhaynes-maslow@ncsu.edu

'Department of Agricultural \& Human Sciences, NC State University, 512

Brickhaven Drive, Room 240c, Raleigh, NC 27695, USA

Full list of author information is available at the end of the article
}

C C The Author(s). 2021 Open Access This article is licensed under a Creative Commons Attribution 4.0 International License, which permits use, sharing, adaptation, distribution and reproduction in any medium or format, as long as you give appropriate credit to the original author(s) and the source, provide a link to the Creative Commons licence, and indicate if changes were made. The images or other third party material in this article are included in the article's Creative Commons licence, unless indicated otherwise in a credit line to the material. If material is not included in the article's Creative Commons licence and your intended use is not permitted by statutory regulation or exceeds the permitted use, you will need to obtain permission directly from the copyright holder. To view a copy of this licence, visit http://creativecommons.org/licenses/by/4.0/. The Creative Commons Public Domain Dedication waiver (http://creativecommons.org/publicdomain/zero/1.0/) applies to the data made available in this article, unless otherwise stated in a credit line to the data. 


\section{Introduction}

Adequate consumption of fruits and vegetables, whole grains, healthy oils, and lean protein is essential for optimal health throughout the lifespan [1]. However, the ability to maintain healthy eating patterns is contingent upon availability, affordability, and acceptability of healthy foods and beverages [2-5]. Maintaining healthy eating patterns is even more difficult for rural and lowincome populations, which may contribute to the higher rates of diet-related chronic diseases observed in these communities [6-8]. Studies indicate such residents face significant barriers when attempting to purchase healthy foods and beverages, including economic barriers, lack of adequate transportation, and residence in a food desert (too few healthy food venues) or a food swamp (too many venues offering less healthy foods and beverages) are commonly cited barriers $[9,10]$.

One of the reasons for this limited access to healthy food is that there is a high prevalence of small food stores that do not stock healthier food options [9-14]. Residents of these communities, particularly those with limited transportation, often rely on these stores as a major source of food [9, 12-14]. Generally, these stores do not offer a wide variety of healthier foods and beverages [11]. To improve access to healthy foods and beverages in rural and underserved areas, healthy corner store policies have been implemented across a number of jurisdictions $[15,16]$. Indeed, several states have passed legislation designed to facilitate the sale of healthy foods and beverages through small food retailers to increase access to healthy foods in areas where there is limited access [17]. These legislative efforts vary considerably in their scope, the mechanisms used to incentivize store participation, and the agencies assigned to implement these programs.

To date, research on healthy corner store policies suggests they generally improve customers' intent to consume healthier foods and beverages $[16,18]$ and increase availability of healthier foods and beverages $[15,19,20]$. However, mixed quantitative findings regarding whether healthy corner store policies improve the nutritional quality of customers' diets have hindered our understanding of their impacts [20-24]. Qualitative data may help elucidate a deeper understanding of influential factors not fully captured by quantitative measurement. Therefore, the purpose of this study was to qualitatively examine customer perceptions among regular shoppers at stores participating in the North Carolina Healthy Food Small Retailer Program (NC HFSRP) [25]. We sought to understand regular customers' views of the healthier selections, if they supported the NC HFSRP, and if their food and beverage choices had been impacted by the healthier options available through the NC HFSRP.

\section{Methods}

The North Carolina healthy food small retailer program The NC HFSRP was established to provide funding for small food retailers located in United States Department of Agriculture (USDA)-defined food deserts to increase stocking of healthy foods and beverages with the hope of improving the eating patterns of local residents and benefiting small food retailers [25]. According to the USDA, census tracts are considered a food desert if they are both low-income and have low food access [26]. Low-income census tracts are those with poverty rates equal to or greater than $20 \%$ or a median household income that does not exceed $80 \%$ of the state's median household income (rural/urban) or urban area median household income. Low food access is defined as at 33\% of the population living more than 1 mile (urban) or 10 miles (rural) from the nearest supermarket or large grocery store [26]. Beginning in 2016 and through 2018, the NC Legislature appropriated $\$ 250,000$ annually to fund the NC HFSRP. The NC Department of Agriculture and Consumer Services served as the implementing agency. This program was available for small food retailers (with less than 3000 heated square feet of retail space) who were willing to (or already did) accept Supplemental Nutrition Assistance Program (SNAP) and the Special Supplemental Nutrition Program for Women, Infants, and Children (WIC) benefits.

Small food retailers were eligible to apply for grants up to $\$ 25,000$. These funds could be used to purchase and install equipment necessary for stocking nutrient-dense foods and beverages, including fresh vegetables and fruits, whole grains, nuts, seeds, beans and legumes, lowfat dairy products, lean meats, and seafood [27]. In this qualitative study, we examined perceptions of the NC HFSRP overall, perceived changes in the food store environment of participating stores, and changes in customers' purchasing and/or consumption habits. This data collection effort was part of a larger mixed-methods independent evaluation of the impact of the NC HFSRP on the store food environment as well as purchasing and consumption habits among customers [28]. This study includes three of the six stores from the first year of funding, and two of the five stores from the second year of funding [27].

\section{Study setting and participants}

In-depth, semi-structured interviews were conducted with 29 customers from five NC HFSRP stores. Selection of HFSRP stores occurred on a rolling basis through an application process [27]. Stores voluntarily applied to be in the HFSRP. For this study, the qualitative customer interviews took place in HFSRP stores located in five eastern North Carolina counties (Bertie, Halifax, Onslow, Pasquotank, and Edgecombe). See Table 1. 
Table 1 County characteristics for the five counties where Healthy Food Small Retailer Program (HFSRP) stores were located, in which customers were interviewed

\begin{tabular}{|c|c|c|c|c|c|}
\hline County & Percent Poverty & $\begin{array}{l}\text { Percent Food } \\
\text { Insecurity }\end{array}$ & $\begin{array}{l}\text { Percent obese } \\
\text { adults }\end{array}$ & $\begin{array}{l}\text { Distance from store in that county } \\
\text { to closest grocery store (miles) }\end{array}$ & $\begin{array}{l}\text { Percent with a bachelor's degree } \\
\text { or higher (ages } 25 \text { and older) }\end{array}$ \\
\hline Bertie & $24.2 \%$ & $22.0 \%$ & $43.0 \%$ & 13.7 & $13.6 \%$ \\
\hline Edgecombe & $21.0 \%$ & $24.0 \%$ & $38.0 \%$ & 1.07 & $13.6 \%$ \\
\hline Halifax & $23.8 \%$ & $24.0 \%$ & $44.0 \%$ & 15.3 & $14.4 \%$ \\
\hline Onslow & $12.5 \%$ & $15.0 \%$ & $29.0 \%$ & 5.41 & $22.9 \%$ \\
\hline Pasquotank & $14.3 \%$ & $19.0 \%$ & $39.0 \%$ & 1.83 & $22.1 \%$ \\
\hline \multicolumn{6}{|l|}{ State } \\
\hline North Carolina & $13.6 \%$ & $13.9 \%$ & $34.0 \%$ & - & $31.3 \%$ \\
\hline
\end{tabular}

Sources

https://www.census.gov/quickfacts/fact/table/

pasquotankcountynorthcarolina,onslowcountynorthcarolina,halifaxcountynorthcarolina,edgecombecountynorthcarolina,bertiecountynorthcarolina,NC/PST045219 https://www.countyhealthrankings.org/app/north-carolina/2020/rankings/bertie/county/outcomes/overall/snapshot

https://www.countyhealthrankings.org/app/north-carolina/2020/rankings/pasquotank/county/outcomes/overall/snapshot

https://www.countyhealthrankings.org/app/north-carolina/2020/rankings/halifax/county/outcomes/overall/snapshot

https://www.countyhealthrankings.org/app/north-carolina/2020/rankings/onslow/county/outcomes/overall/snapshot

https://www.countyhealthrankings.org/app/north-carolina/2020/rankings/onslow/county/outcomes/overall/snapshot

https://www.countyhealthrankings.org/app/north-carolina/2020/measure/factors/139/data

https://www.census.gov/quickfacts/fact/table/NC/PST045219

https://stateofchildhoodobesity.org/adult-obesity/

https://www.americashealthrankings.org/explore/health-of-women-and-children/measure/food_insecurity_household/state/NC

Customers were approached on weekdays, during normal business hours, and asked if they were interested in completing a 10-15 minute interview. In each of the five stores, between 3 to 10 participants were recruited and consented to being interviewed. Participant eligibility criteria included: being a self-defined 'regular' customer of the store, at least 18 years of age, and able to speak and understand English. Interviews were conducted by the study's principal investigator or trained research assistants. Interviews were digitally recorded and notes were taken on paper, and then interviews were transcribed verbatim using an online transcription service. Participants were compensated for their time with a $\$ 10$ Walmart gift card upon interview completion. The study was reviewed and approved by the East Carolina University Institutional Review Board [UMCIRB 16-002420]. All participants signed an informed consent form.

\section{Semi-structured interview guide}

Data were collected using semi-structured interviews to learn more about customers' perspectives of the NC HFSRP. An interview guide was developed through several meetings of the research team. Questions focused on shoppers' food and beverage purchases at NC HFSRP stores ("Have your food or beverage purchasing habits at this store changed since the program began?"; "Has the overall amount of healthy food or beverage items you buy changed since this store started carrying healthier foods?"; and, "Has the overall amount of healthy food or beverage items you consume changed since the store starting carrying healthier foods?"); whether they had noticed any in-store efforts to promote healthier foods and beverages, their suggestions for promoting healthier foods and beverages, their familiarity with and support of the NC HFSRP, and how their shopping and consumption habits had changed since implementation of the NC HFSRP. Participants were also asked to provide basic demographic information including gender, age, race, ethnicity, educational attainment, and household income.

\section{Data analysis}

First, three transcripts were independently reviewed by the principal investigator, study coordinator, and two graduate research assistants. Each member of the research team prepared an independent codebook consisting of codes, operational definitions, and illustrative quotes. Codes included those derived from the interview guide (deductive codes) and those that emerged from the interview data (inductive codes). The research team then discussed their independently-developed codebooks to create a consensus codebook which was subsequently used to code all transcripts. Each transcript was double-coded (separately coded by each of two research team members), and these codes were reconciled in a series of consensusbuilding meetings between team members. Reconciled and coded transcripts were uploaded into NVivo (Version 12, QSR International, Melbourne, Australia), and reports were generated for each code. A thematic analysis was conducted based on code frequency, and depth of participant responses for each code [29].

\section{Results}

A summary of participant self-reported demographic characteristics is presented in Table 2. Among the 29 
Table 2 Participant Demographics among Customers of Stores in the North Carolina Healthy Food Small Retailer Program ( $N=$ 29)

\begin{tabular}{|c|c|c|}
\hline Characteristic & Frequency & Percent \\
\hline \multicolumn{3}{|l|}{ Gender } \\
\hline Male & 12 & 41 \\
\hline Female & 17 & 59 \\
\hline Other & 0 & 0 \\
\hline Prefer not to answer & 0 & 0 \\
\hline \multicolumn{3}{|l|}{ Age } \\
\hline $18-29$ & 6 & 21 \\
\hline $30-49$ & 7 & 24 \\
\hline $50-64$ & 10 & 35 \\
\hline $65+$ & 4 & 14 \\
\hline Prefer not to answer & 2 & 7 \\
\hline \multicolumn{3}{|l|}{ Race/ethnicity } \\
\hline American Indian or Alaskan Native & 1 & 3 \\
\hline Asian & 0 & 0 \\
\hline Black or African American & 16 & 55 \\
\hline Native Hawaiian or Pacific Islander & 0 & 0 \\
\hline Hispanic or Latino & 0 & 0 \\
\hline White & 12 & 41 \\
\hline Other & 0 & 0 \\
\hline Prefer not to answer & 0 & 0 \\
\hline \multicolumn{3}{|l|}{ Education attainment } \\
\hline Less than high school & 0 & 0 \\
\hline Some high school & 3 & 10 \\
\hline High School/GED & 10 & 35 \\
\hline Associate/Technical Degree & 4 & 14 \\
\hline Some College or More & 12 & 41 \\
\hline \multicolumn{3}{|l|}{ Annual household income } \\
\hline Less than $\$ 25,000$ & 6 & 21 \\
\hline$\$ 25,000$ to $\$ 50,000$ & 10 & 35 \\
\hline$\$ 50,000$ to $\$ 75,000$ & 1 & 3 \\
\hline$\$ 75,000+$ & 6 & 21 \\
\hline Don't know & 3 & 10 \\
\hline Prefer not to answer & 3 & 10 \\
\hline \multicolumn{3}{|l|}{ Employment status } \\
\hline Full-time & 15 & 52 \\
\hline Part-time & 6 & 21 \\
\hline Unemployed & 5 & 17 \\
\hline Retired & 3 & 10 \\
\hline
\end{tabular}

participants, the majority were female (59\%) and the majority were between 18 and 64 years of age. Approximately 55\% were Black/African American, 41\% White, and 3\% American Indian/Alaska Native. Nearly 45\% had a high school degree or less. Half of the participants (52\%) were employed full-time.

Through coding, six main themes emerged from the interviews based on frequency of the code and depth of discussion. These themes included the following, in order of frequency of codes: 1) Change in food purchasing behavior; 2) Stocking suggestions for additional healthy food items; 3) Awareness of current healthy food promotion and advertising efforts; 4) Suggestions for how to promote healthy foods and beverages in the future; 5) Opinions on the NC HFSRP; and, 6) Opinions concerning NC HFSRP funding. Table 3 describes each theme and its operational description, as well as the number of interviews in which each theme is referenced, and the total number of references for each theme.

\section{Change in food purchasing behavior}

Table 4 includes questions, responses, and illustrative quotes regarding NC HFSRP-related purchase and consumption changes. This theme was most frequently discussed by participants. When asked if their food and beverage purchasing behaviors at the store had changed since the NC HFSRP, 15 (52\%) said "yes" they had increased healthy food purchasing. Most participants indicated they now purchased more fruits, vegetables, and whole grains than before NC HFSRP implementation. One participant even commented on a store's locally made granola, "I do have a 15 year-old son. I would say buying this granola instead of store granola, I think this is better. And it's trickled down to my husband and my son, and they truly like it." [White Female, Edgecombe County]. Another commented, "usually I have to take a 30-minute ride to buy an apple. Now I can ride five minutes up the road and buy one." [White Male, Halifax County]. Importantly, having the convenience of purchasing healthier items appeared to be connected with increased purchases. Overall, participants reported that having healthier items at the corner store closer to their home saved them from having to drive further distances to grocery stores, supermarkets, or supercenters to get fresh produce or a variety of healthy food items.

When asked if the overall amount of healthy food or beverage items they purchased from the store changed since the NC HFSRP, 15 (52\%) participants reported that the amount had increased, 10 (34\%) stated it stayed the same, and $4(14 \%)$ had no response or were not asked the question. A participant remarked that now they put more thought into their food and beverage purchases: "... I used to be just a straight junk food kid, but now I try to balance it out." [Black/African American Male, Onslow County]. Many participants discussed purchasing healthier foods and beverages from the store for family members, friends, and even co-workers. For example, when asked if her purchasing habits had changed, 
Table 3 Code, Operational Definitions, and Code Frequency for Qualitative Analysis of data collected among Customers of North Carolina Healthy Food Small Retailer Program Stores ( $\mathrm{N}=29)$

\begin{tabular}{|c|c|c|c|c|}
\hline Code & Operational Definitions & $\begin{array}{l}\text { Number of } \\
\text { Interviews } \\
\text { where the code } \\
\text { Referenced }\end{array}$ & $\begin{array}{l}\text { Total Number } \\
\text { of References } \\
\text { for the Code }\end{array}$ & Illustrative Quote \\
\hline $\begin{array}{l}\text { Change in Food } \\
\text { Purchasing Behavior }\end{array}$ & $\begin{array}{l}\text { Participant describes changes } \\
\text { in their purchasing and } \\
\text { consumption of healthier foods } \\
\text { based on the HFSRP }\end{array}$ & 29 & 123 & $\begin{array}{l}\text { "We buy more fish. We almost never buy } \\
\text { meat. We spent a lot of time in the produce } \\
\text { section." [Edgecombe County, Male] } \\
\text { "Instead of getting her [daughter] a piece of } \\
\text { pizza, I bought her two bananas" [Bertie County, } \\
\text { Female] }\end{array}$ \\
\hline $\begin{array}{l}\text { Stocking Suggestions } \\
\text { for Additional Healthy } \\
\text { Food Items }\end{array}$ & $\begin{array}{l}\text { Participant describes items } \\
\text { they would like to see in } \\
\text { the store which are not } \\
\text { currently in the store. }\end{array}$ & 28 & 43 & $\begin{array}{l}\text { "If they had grilled fish instead of fried fish, I would } \\
\text { absolutely buy that instead." [Bertie County, Female] }\end{array}$ \\
\hline $\begin{array}{l}\text { Opinions on the NC } \\
\text { HFSRP }\end{array}$ & $\begin{array}{l}\text { Participant describes what } \\
\text { they think about the HFSRP }\end{array}$ & 29 & 37 & $\begin{array}{l}\text { "I think it's wonderful that they [the store] can get } \\
\text { something out of it for all they give back." } \\
\text { [Edgecombe County, Male] }\end{array}$ \\
\hline $\begin{array}{l}\text { Awareness of Current } \\
\text { Healthy Food Promotion } \\
\text { and Advertising Efforts }\end{array}$ & $\begin{array}{l}\text { Participant describes health } \\
\text { promotion/ nutrition promotion } \\
\text { efforts of the store owner }\end{array}$ & 29 & 31 & $\begin{array}{l}\text { "They've added these fruits and veggies, and they } \\
\text { have some really cool alternative drinks to soda." } \\
\text { [Edgecombe County, Male] }\end{array}$ \\
\hline $\begin{array}{l}\text { Suggestions for How to } \\
\text { Promote Healthy Foods } \\
\text { and Beverages in the } \\
\text { Future }\end{array}$ & $\begin{array}{l}\text { Participant describes other } \\
\text { strategies used to make healthier } \\
\text { choices easier for customers } \\
\text { to make. }\end{array}$ & 29 & 30 & $\begin{array}{l}\text { "I think they could use social media to a stronger } \\
\text { degree." [Edgecombe County, Male] }\end{array}$ \\
\hline $\begin{array}{l}\text { Opinions Concerning } \\
\text { NC HFSRP Funding }\end{array}$ & $\begin{array}{l}\text { Participant response to } \\
\text { whether or not the HFSRP } \\
\text { should continue to be funded }\end{array}$ & 28 & 28 & $\begin{array}{l}\text { "I think it sounds like a great program to fund." } \\
\text { [Edgecombe County, Female] }\end{array}$ \\
\hline
\end{tabular}

one mother said, "I noticed today when I came in that they [the store] had bananas on the rack, so we ended up grabbing one of those. My daughter loves fruits so if those are available at a gas station, we buy those." [White Female, Bertie County]. Others noticed the healthier options in the store but had opted not to buy them.
In terms of food or beverage consumption changes since the NC HFSRP, participants were asked if the healthy food items they purchased in the store were in addition to the items they would normally buy or if they were purchasing healthier food and beverages instead of less healthy food options. Among the 27 participants who responded to this question, 12 (41\%) indicated that

Table 4 Changes in Food Purchasing and Consumption Behavior among Customers in North Carolina Healthy Food Small Retailer Program Stores ( $n=29$ customers in 5 stores)

\begin{tabular}{|c|c|c|}
\hline $\begin{array}{l}\text { Change in Food Purchasing and Consumption } \\
\text { Behavior }\end{array}$ & $\begin{array}{l}\text { Responses and (\%) } \\
\text { Responding }^{\mathrm{a}}\end{array}$ & Illustrative quote \\
\hline $\begin{array}{l}\text { Have your food or beverage purchasing habits } \\
\text { at this store changed since the program began? }\end{array}$ & $\begin{array}{l}\text { Increased purchase of healthy } \\
\text { foods at the store: } \\
15 / 29,52 \% \\
\text { No change in purchases at the store: } \\
13 / 29,45 \%\end{array}$ & $\begin{array}{l}\text { Interviewer: Overall, has your food or beverage purchasing } \\
\text { habits at this store changed since the program began? } \\
\text { Respondent: They actually have ... I hadn't seen them in a } \\
\text { while like the tangerines in the cup and ... I've actually } \\
\text { ate more tangerines and fruits in the cup and stuff because } \\
\text { they're there now. [Pasquotank County, Male] }\end{array}$ \\
\hline $\begin{array}{l}\text { Has the overall amount of healthy foods or beverage } \\
\text { items you buy changed since the store started } \\
\text { carrying healthier foods? }\end{array}$ & $\begin{array}{l}\text { Yes, increased purchase of healthy } \\
\text { foods: } \\
\text { 14/29, } 48 \% \\
\text { No, healthy food purchases have } \\
\text { stayed the same: } 13 / 29,44 \%\end{array}$ & $\begin{array}{l}\text { Interviewer: Has the overall amount of healthy foods or } \\
\text { beverage items you buy changed since the store started } \\
\text { carrying healthier foods? } \\
\text { Respondent: I do buy more bananas because they're right } \\
\text { there. [Bertie, Female] }\end{array}$ \\
\hline $\begin{array}{l}\text { Has the overall amount of healthy food or beverage } \\
\text { items you consume changed since the store started } \\
\text { carrying healthier foods? }\end{array}$ & $\begin{array}{l}\text { Purchasing healthy food in addition } \\
\text { to regular purchases: } 12 / 29,41 \% \\
\text { Purchasing healthier food instead of } \\
\text { less healthy food } \\
8 / 29,28 \% \\
\text { Unsure about consumption changes: } \\
7 / 29,14 \%\end{array}$ & $\begin{array}{l}\text { Interviewer: When you purchase these healthier items, are } \\
\text { you picking these items in addition to items that you } \\
\text { typically buy or are you buying them instead of less } \\
\text { healthy options? } \\
\text { Respondent: In addition. Yeah. I think this is one of the } \\
\text { few places in Tarboro at least that gives you the healthier } \\
\text { options. [Edgecombe County, Male] }\end{array}$ \\
\hline
\end{tabular}


they were purchasing healthy food in addition to their regular purchases (healthy food complements to existing purchases). An additional eight respondents (28\%) indicated that they were purchasing healthier food instead of less healthy food (substituting healthier foods for less healthy food), and seven (24\%) were not sure of the impact the healthy foods on their shopping habits. One participant responded he bought healthier food in addition to his regular store purchases, stating: "This is one of the few places in [town name] that at least gives you the healthier options." [White Male, Edgecombe County]. One caregiver commented that she was buying healthy food in lieu of unhealthy food for her daughter: "Instead of getting her a piece of pizza, I bought her two bananas. She loves bananas." [White Female, Bertie County].

\section{Stocking suggestions for additional healthy food items}

Across the interviews, participants offered 43 suggestions concerning what healthy food or beverage items they would like to see added to their store's inventory. Fruits were the most popular response $(n=16)$; specific suggestions included fruit cocktail, apples, oranges, grapes, and plums. Other suggestions included vegetables $(n=3)$ and pre-made salads $(n=3)$.

\section{Awareness of current healthy food promotion and advertising efforts}

When asked if participants noticed any changes to the ways the store promoted healthier food and beverages over the past few months, 17 of 29 participants said "yes." When asked what they had noticed, most noted increased quantity and variety of produce, signs and other promotional materials related to healthy foods, and new equipment. As one participant said, "They've added these fruits and veggies, and they have really cool alternative drinks to soda." [White Male, Edgecombe County]. Another participant noticed the store started accepting federal food assistance benefits, the Supplemental Nutrition Assistance Program (SNAP), formerly referred to as "food stamps": "They even do the EBT (SNAP Electronic Benefit Transfer). They do that, which I think is really nice, because a lot of the organic kind of places aren't really geared toward that. And ... we're a very poor community, and I think it's awesome that she [the store owner] does this." [White Female, Edgecombe County]. Some participants recalled seeing free recipe cards associated with healthy food items sold at the store, as well as promotional signs: "Advertising's always the key to anything and what she [the store owner] started doing now with the signs, that makes a big difference. People have to know what you have to be able to come get it." [Black/African American Male, Pasquotank County].
Suggestions for how to promote healthy foods and beverages in the future

Multiple suggestions were offered regarding additional approaches stores could use to promote healthy items. Many people suggested advertising via social media and at community functions. As one participant said, “... you just have to advertise that a little bit more so people know exactly what's in here ...." [Black/African American Female, Pasquotank County]. Another participant suggested more outdoor advertising so people driving by could see what was available in the store. Additionally, several participants discussed wanting more nutrition information regarding specific food and beverages: "Put the little signs that it breaks down the calories and the nutrients, or what fruit has vitamin $C$ in it or what had vitamin D in it. Just have one of those charts up." [Black/ African American Male, Onslow County].

Opinions on the NC healthy food small retailer program While participants recognized healthy changes in the stores, among the 29 participants, only three were aware of the NC HFSRP. After explaining the premise of the program, all 29 participants agreed it was a program that could provide benefits to the community. In addition, several participants noted the program could benefit youth in their (rural) communities since they often purchase items from these stores. As one participant commented:

"I think it's good because you got kids, little kids that come here. You know and they want stuff. And before it was like just a lot of junk food, but now, you've got healthy stuff like vegetables and fruits that are constantly being changed out now. This is perfect because my friend, she lives across the road. She's got kids and they always say, 'I want junk food.' But now I can go, 'Hey, instead of junk food, how about an apple?'” [White Male, Pasquotank County].

Multiple participants liked the goal of improving healthy options in their rural area. One woman who said the program was "awesome" went on to say, "In these types of neighborhoods, if you put a store with fresh fruits and have different variety ... like a lot of people don't have a car." [Black/African American Female, Pasquotank County]. Another commented that for rural communities, this program is important for healthy food access: "... because I like to eat the vegetables and have fruit. Then I won't have to go all the way to town. I can just come right here and get it." [Black/African American Female, Bertie County]. Lastly, many participants discussed health issues. When one participant was asked what influenced her to buy healthy food/beverages, she said, "That everybody in my family got high blood pressure ... 
My mom had it. My dad. I got three brothers living. I got a son. Two nephews. Yes. It's there." [Black/African American Female, Bertie County]. Participants noted the healthier options facilitated a healthier lifestyle that was important to prevent or ameliorate diet-related chronic diseases.

\section{Opinions concerning NC HFSRP funding}

While most participants had never heard of the NC HFSRP, when asked if the NC Legislature should continue funding it, all responded "yes". Some explained their reasoning by stating it helped increase rural food access and it was good for health: "I hope they will [fund it]. It would help us a lot. Living out here in the county, you can't always go to the store. Having stuff like this is helping us and everybody else too." [Black/African American Female, Halifax County]. Another commented, "I feel like if that's going to be a program that's going to help people, especially when it comes to health and then trying to actually put food in someone's home, then yeah, I feel like they should definitely fund that." [Black/ African American Male, Onslow County]. Another participant focused on program efficacy, stating, "If it's working or if it's profitable, you know, doing what it's supposed to do, and the funds are actually going where they should go. Yeah [the legislature should fund it]." [White Male, Onslow County].

\section{Discussion}

This study's findings provide a deeper understanding of the impact of the NC HFSRP program from the perspective of customers. Although few participants knew about the NC HFSRP, they were aware of changes within the store and some customers reported that the changes encouraged increased purchasing of healthier foods and beverages. When a description of the NC HFSRP was provided to study participants, all approved of the state funded program's purpose. Participants discussed the benefits of the program, including increased healthy food access in their rural and underserved communities, which they felt was especially important for youth and individuals with diet-related chronic diseases. There was also an overall agreement that being able to purchase healthier food and beverages closer to home - instead of driving long distances to larger stores - was helpful. Participants provided suggestions for further improvements to store offerings, including more pre-cut and fresh fruit options. Lastly, participants discussed the importance of marketing and advertising healthier foods and beverages in the stores.

There were mixed responses in terms of the NC HFSRP changing customers' shopping habits regarding the amount of healthy food and beverage items purchased and increases in healthy food and beverage consumption. Overall, approximately half of participants reported making healthier food and beverage changes either through changing their overall shopping habits, changing amounts of healthy foods/beverages purchased, and/or types/amounts consumed. Other studies have found limited evidence of healthy corner store conversions and healthy food policies impacting dietary behaviors among customers [30-32]. For example, in two California food swamps, researchers found that among three corner stores that made in-store changes to promote the purchase and consumption of healthy foods and beverages, no changes were found among customers [30]. However, there were improvements in perceived healthy food access and more positive perceptions of corner stores [30]. Another study that evaluated the impact of the Minneapolis 2015 Staple Food Ordinance, which mandated minimum healthy food and beverage stocking requirements in small stores, found there was little impact on healthy food purchases by customers that frequented these stores [24]. However, it is important to recognize that shifting eating patterns is not an easy, nor quick, process, often taking both individuallevel and policy and environmental-level changes to support healthier food and beverage choices [31, 32]. It should also be noted that among small retail food outlets represent a relatively small amount of overall food and beverage purchasing, compared to other retail food outlets [33]. In a systematic review of 64 studies focused on improving healthy food consumption and purchases in the retail environment, Karpyn and colleagues found that 56 studies showed at least one positive effect [32].

One limitation with the NC HFSRP's implementation was that, even in the areas targeted by the program, relatively few customers in participating stores were aware of the program. This was frequently true even in cases where respondents had noticed changes in the store since its inception. As state funding for programs can be contingent upon perceived success and satisfaction among taxpayers, this is an important observation. While all participants in this study agreed that the NC Legislature should continue funding the program, going forward, it would be helpful to communicate more explicitly that the store changes are supported by the NC HFSRP. While the NC HFSRP did not include funding for advertising or branding, some stores partnered with local health departments, nutrition education programs such as SNAP-Education, or other local organizations to help purchase some marketing materials. This supports the need for both individual (educationally- and knowledge-based) as well as structural (policy and environmental change) strategies for promoting healthy eating among underserved populations [34].

Given the political importance of legislators being recognized for positive policies implemented in the 
community, and the potential benefit to sustaining such policies, including funds in the legislation for marketing and branding is important. In the case of the $\mathrm{NC}$ HFSRP, funding was limited to equipment purchases only. Additional funding for technical assistance and marketing could potentially have increased healthy food purchasing, as well as policy awareness, thus strengthening the case for this legislation.

This study found that many participants valued the state funded program because it increased overall convenient access to healthier food and beverages in rural communities. In addition, participants recognized that children shop at these stores without adult supervision; this program thus can foster opportunities for children to be exposed to healthier food and beverage choices. Participants also noted their shopping habits may have changed for the better due to desires to improve their health due to diet-related chronic diseases. When passing legislation, political battles are usually won based on framing arguments that resonate with public opinion and political will [35]. Therefore, in terms of future healthy corner store state-wide policies, stakeholders could frame arguments for the policy around healthy food access, improving children's dietary choices and health and providing those with health problems alternative, healthier choices [36, 37]. In terms of political will, the HFSRP bill was co-sponsored by both Democrat and Republican legislators. It also passed with overwhelming bi-partisan support, likely due to the emphasis on supporting small businesses in rural communities as well as providing healthy food for residents of food deserts [25].

This study has several strengths. As one of the first studies to examine customer's perceptions of a statewide policy to improve healthy purchases at small stores in rural and low-income areas, these findings offer insights and fill important gaps in the literature. The customer participants were racially/ethnically diverse and, through a qualitative approach, provided rich perspectives on the program's impact on purchasing decisions.

While this research is novel in its approach, the study scope and setting do introduce some limitations. First, it is limited in geographic scope (five counties in one state) and sample size ( 29 customers) and therefore its findings have limited generalizability. Because customers were interviewed at the store, their responses could have been biased to be more socially desirable than they may otherwise have been due to the presence of store personnel. While one store's NC HFSRP contract was pending at the time of the interviews, this store had not yet received the equipment for the program at the time of the interviews. However, the retailer had received similar equipment from another program. Lastly, some of the participants that agreed to be interviewed may have been more health conscious than others.

\section{Conclusions}

Given the increasing number of healthy corner store policies, [17] the results of this study will be useful to both offer grounded insights into potential impacts of resource allocations towards environmental supports that promote healthy eating. Additionally, this study could help inform an approach other jurisdictions could adopt to evaluate their own programs. Our findings can inform future healthy corner store initiatives in terms of framing the rationale for funding - including improving food access in low-income areas, and empowering youth and those with diet-related chronic diseases to select healthier foods and beverages when in smaller food retail stores. More research is needed to determine the cost/ benefit ratio of various state investments in promoting healthy eating among rural communities, as well as determine the level of support retail stores need to stock and promote healthier foods and beverages in a sustainable way. Future policies of this type could purposively include language and funding related to marketing as well as partnering with local health departments, SNAPEducation programs, or cooperative extension offices to promote purchase and consumption of the healthier options, ultimately to increase demand, financial sustainability, and overall health of rural and underserved communities.

\section{Acknowledgements \\ We gratefully acknowledge the time and attention from our study participants. \\ Authors' contributions \\ LHM, SBJP, KAB, ASA, JTM, SF, RAB and MNL contributed to design of the study. LHM and SBJP drafted the manuscript. SBJP, NSJ, CJK, VED, and LHM collected and/or organized and analyzed the data. All authors read and approved the final manuscript. \\ Funding \\ This project was funded by the Robert Wood Johnson Foundation Policies for Action grant, 76101, PI: Stephanie Jilcott Pitts. This project was funded in part by the Department of Public Health at East Carolina University. The funders had no role in data collection, analysis or the writing of the manuscript.}

\section{Availability of data and materials \\ The (deidentified) datasets used and/or analysed during the current study are available from the corresponding author on reasonable request.}

\section{Declarations}

Ethics approval and consent to participate

The study was reviewed and approved by the East Carolina University Institutional Review Board (study number UMCIRB 16-002420). Written informed consent was obtained by participants before all interviews were conducted. This research was performed in accordance with the Declaration of Helsinki.

Consent for publication

Not applicable.

Competing interests

The authors declare that they have no competing interests. 


\section{Author details}

'Department of Agricultural \& Human Sciences, NC State University, 512 Brickhaven Drive, Room 240c, Raleigh, NC 27695, USA. ${ }^{2}$ Department of Public Health, East Carolina University, 115 Heart Drive, Room \#2239, Greenville, NC 27834, USA. ${ }^{3}$ Department of Agricultural and Resource Economics, North Carolina State University, 4306 Nelson Hall, Raleigh, NC 27695-8109, USA. ${ }^{4}$ Department of Nutrition, University of North Carolina Greensboro, 319 Colllege Avenue, 318 Stone Building, Greensboro, NC 27412, USA. ${ }^{5}$ Georgetown University, Law Center, Washington, DC, USA. ${ }^{6}$ Department of Nutrition, University of North Carolina at Chapel Hill, CB\# 7426, 1700 MLK Jr. Blvd, Room 239, Chapel Hill, NC 27599-7426, USA. 'University of North Carolina at Chapel Hill, School of Medicine, Division of Geriatric Medicine, Center for Aging and Health, 5003 Old Clinic CB\#7550, Chapel Hill, NC 27599, USA. ${ }^{8}$ Department of Social Sciences and Health Policy, Division of Public Health Sciences, Wake Forest School of Medicine, Medical Center Boulevard, Winston-Salem, NC 27157, USA. ${ }^{9}$ Epidemiology \& Community Health, University of Minnesota, 1300 South 2nd Street, WBOB Suite 300, Minneapolis, MN 55454-1015, USA.

\section{Received: 28 January 2021 Accepted: 10 June 2021}

Published online: 27 July 2021

\section{References}

1. 2015-2020 Dietary Guidelines for Americans. 8th ed. Washington, DC: U.S. Department of Health and Human Services and U.S. Department of Agriculture; 2015. https://health.gov/our-work/food-and-nutrition/2015-202 0-dietary-guidelines. Accessed 8 June 2020.

2. Glanz K, Sallis JF, Saelens BE, Frank LD. Healthy nutrition environments: concepts and measures. Am J Health Promot. 2005;19(5):330-3. https://doi. org/10.4278/0890-1171-19.5.330.

3. Caspi CE, Lenk K, Pelletier JE, Barnes TL, Harnack L, Erickson DJ, et al. Food and beverage purchases in corner stores, gas-marts, pharmacies and dollar stores. Public Heal Nutr. 2017;20(14):2587-97. https://doi.org/10.1017/S13 68980016002524.

4. Andress L, Fitch C. Juggling the five dimensions of food access: perceptions of rural low income residents. Appetite. 2016;105:151-5. https://doi.org/10.1 016/j.appet.2016.05.013.

5. United States Department of Agriculture - Economic Research Service. Food Access. https://www.ers.usda.gov/topics/food-choices-health/food-access/. Accessed 4 Sept 2017

6. Blanchard T, Lyson T. Food Availability and Food Deserts in the Nonmetropolitan South. Vol Number 12. Southern Rural Development Center; 2006. http://srdc.msstate.edu/publications/other/foodassist/2006_ 04 blanchard.pdf.

7. Tai-Seale T, Chandler C. Nutrition and Overweight Concerns in Rural Areas: A Literature Review. In: Rural Healthy People 2010: A companion document to healthy people 2010. Vol 2. College Station: The Texas a\&M University System Health Science Center, School of Rural Public Health, Southwest Rural Health Research Center; 2003. p. 115-130. http://www.srph.tamushsc. edu/srhrc. Accessed 16 June 2020.

8. Befort CA, Nazir N, Perri MG. Prevalence of obesity among adults from rural and urban areas of the United States: findings from NHANES (2005-2008). J Rural Heal. 2012;28(4):392-7. https://doi.org/10.1111/j.1748-0361.2012.00411.x.

9. Larson NI, Story MT, Nelson MC. Neighborhood Environments: Disparities in Access to Healthy Foods in the U.S. Am J Prev Med. 2009;36(1):74-81.e10. https://doi.org/10.1016/j.amepre.2008.09.025.

10. Powell LM, Slater S, Mirtcheva D, Bao Y, Chaloupka FJ. Food store availability and neighborhood characteristics in the United States. Prev Med. 2007;44(3): 189-95. https://doi.org/10.1016/.ypmed.2006.08.008.

11. Liese AD, Weis KE, Pluto D, Smith E, Lawson A. Food store types, availability, and cost of foods in a rural environment. J Am Diet Assoc. 2007;107(11): 1916-23. https://doi.org/10.1016/j.jada.2007.08.012.

12. McGuirt JT, Jilcott Pitts SB, Ammerman A, et al. A mixed methods comparison of urban and rural Retail corner stores. AIMS Public Heal. 2015; 2(3):554-82. https://doi.org/10.3934/publichealth.2015.3.554

13. D'Angelo H, Ammerman A, Gordon-Larsen P, Linnan L, Lytle L, Ribisl KM. Small food store retailers' willingness to implement healthy store strategies in rural North Carolina. J Community Health. 2017:42(1):109-15. https://doi. org/10.1007/s10900-016-0236-0

14. Pinard CA, Byker Shanks C, Harden SM, Yaroch AL. An integrative literature review of small food store research across urban and rural communities in the U.S. Prev Med Reports. 2016;3:324-332. https://doi.org/10.1016/j.pmedr.2 016.03.008.

15. Gittelsohn J, Rowan M, Gadhoke P. Interventions in small food stores to change the food environment, improve diet, and reduce risk of chronic disease. Prev Chronic Dis. 2012;9(110015). https://doi.org/10.5888/pcd9.11 0015.

16. Langellier BA, Garza JR, Prelip ML, Glik D, Brookmeyer R, Ortega AN. Corner store inventories, purchases, and strategies for intervention: a review of the literature. Calif J Heal Promot. 2013;11(3):1-13. https://pubmed.ncbi.nlm.nih. gov/25374481. https://doi.org/10.32398/cjhp.v11i3.1537.

17. State Initiatives Supporting Healthier Food Retail: An Overview of the National Landscape. Centers for Disease Control and Prevention, National Center for Chronic Disease Prevention and Health Promotion, Division of Nutrition, Physical Activity, and Obesity; CDC Publication CS226271; 2011. https://www.cdc.gov/obesity/downloads/healthier_food_retail.pdf. Accessed 19 Dec 2019.

18. Song HJ, Gittelsohn J, Kim M, Suratkar S, Sharma S, Anliker J. A corner store intervention in a low-income urban community is associated with increased availability and sales of some healthy foods. Public Health Nutr. 2009;12(11): 2060-7. https://doi.org/10.1017/S1368980009005242.

19. Cavanaugh E, Green S, Mallya G, Tierney A, Brensinger C, Glanz K. Changes in food and beverage environments after an urban corner store intervention. Prev Med (Baltim). 2014;65:7-12. https://doi.org/10.1016/j. ypmed.2014.04.009.

20. Jilcott Pitts S, Wu Q, Truesdale K, Haynes-Maslow L, McGuirt J, Ammerman A, et al. One-year follow-up examination of the impact of the North Carolina healthy food small retailer program on healthy food availability, purchases, and consumption. Int J Environ Res Public Health. 2018;15(12): 2681. https://doi.org/10.3390/ijerph15122681.

21. Lutfiyya MN, Chang LF, Lipsky MS. A cross-sectional study of US rural adults consumption of fruits and vegetables: Do they consume at least five servings daily? BMC Public Health. 2012;12(280). https://doi.org/10.1186/14 71-2458-12-280

22. Almaguer Sandoval B, Law Y, Young C. Healthier Corner Stores: Positive Impacts and Profitable Changes. Philadelphia: The Food Trust; 2014. http:// thefoodtrust.org/uploads/media_items/healthier-corner-stores-positive-impa cts-and-profitable-changes.original.pdf. Accessed 17 June 2020.

23. Lent MR, Vander Veur S, Mallya G, McCoy TA, Sanders TA, Colby L, et al. Corner store purchases made by adults, adolescents and children: items, nutritional characteristics and amount spent. Public Health Nutr. 2015;18(9): 1706-12. https://doi.org/10.1017/S1368980014001670.

24. Laska MN, Caspi CE, Lenk K, Moe SG, Pelletier JE, Harnack LJ, et al. Evaluation of the first U.S. staple foods ordinance: impact on nutritional quality of food store offerings, customer purchases and home food environments. Int J Behav Nutr Phys Act. 2019;16(83):1-20. https://doi.org/1 0.1186/s12966-019-0818-1.

25. Healthy Food Small Retailer/Corner Store Act. North Carolina General Assembly; 2015. https://www.ncleg.gov/BillLookUp/2015/H250. Accessed 19 Dec 2019.

26. Dutko P, Ver Ploeg M, Farrigan T. Characteristics and influential factors of food deserts, ERR-140, U.S. Department of Agriculture, Economic Research Service, August 2012.

27. Butner F. Healthy food small retailer project 2016-2017-2018-2019. North Carolina Department of Agriculture and Consumer Services, Division of Marketing https:/www.ncagr.gov/markets/healthyFoodSmallRetailer/ documents/HealthyFoodSmallRetailerReport2019.pdf. Accessed 17 Dec 2020.

28. Jilcott Pitts SB, Wu Q., Truesdale KP, et al. A four-year observational study to examine the dietary impact of the North Carolina Healthy Food Small Retailer Program, 2017-2020. Int J Behav Nutr Phys Act. 2021;18(44):1-12. https://doi.org/10.1186/s12966-021-01109-8.

29. Guest G, MacQueen K, Namey E. Applied thematic analysis. Los Angeles: Sage Publications, Inc; 2014. https://doi.org/10.4135/9781483384436.

30. Ortega AN, Albert SL, Chan-Golston AM, Langellier BA, Glik DC, Belin TR, et al. Substantial improvements not seen in health behaviors following corner store conversions in two Latino food swamps. BMC Public Health. 2016;16(1):389. https://doi.org/10.1186/s12889-016-3074-1.

31. Castro I, Majmundar A, Williams C, Baquero B. Customer purchase intentions and choice in food Retail environments: a scoping review. Int J Environ Res Public Health. 2018;15(11):2493. https://doi.org/10.3390/ijerph15112493.

32. Karpyn A, McCallops K, Wolgast H, Glanz K. Improving consumption and purchases of healthier foods in Retail environments: a systematic review. Int 
J Environ Res Public Health. 2020;17(20):7524. https://doi.org/10.3390/ijerph1 7207524.

33. Haynes-Maslow L, McGuirt J, Trippichio G, Armstrong-Brown J, Ammerman AS, Leone LA. Examining commonly used perceived and objective measures of fruit and vegetable access in low-income populations and their association with consumption. Transl Behav Med. 2020;10(6):1342-9. https:// doi.org/10.1093/tbm/ibaa077.

34. Clark-Barol M, Gaddis JE, Barrett CK. Food agency in low-income households: a qualitative study of the structural and individual factors impacting participants in a community-based nutrition program. Appetite. 2021;158:105013. https://doi.org/10.1016/j.appet.2020.105013.

35. Chapman S, Lupton D. The fight for public health: principles and practices for media advocacy. London: BMJ Publishing Group; 1994.

36. Russell C, Lawrence M, Cullerton K, Baker P. The political construction of public health nutrition problems: a framing analysis of parliamentary debates on junk-food marketing to children in Australia. Public Health Nutr. 2019;23(11):1-12. https://doi.org/10.1017/S1368980019003628.

37. Haynes-Maslow L, Schramm D, Mark B, Ammerman A, Silberman P. Stakeholder arguments in access to healthy food state-level legislation in newspapers and bill hearings. J Sci Policy Gov. 2014;6(1). www. sciencepolicyjournal.org. Accessed 17 June 2020

\section{Publisher's Note}

Springer Nature remains neutral with regard to jurisdictional claims in published maps and institutional affiliations.

Ready to submit your research? Choose BMC and benefit from:

- fast, convenient online submission

- thorough peer review by experienced researchers in your field

- rapid publication on acceptance

- support for research data, including large and complex data types

- gold Open Access which fosters wider collaboration and increased citations

- maximum visibility for your research: over $100 \mathrm{M}$ website views per year

At $\mathrm{BMC}$, research is always in progress.

Learn more biomedcentral.com/submissions 